NBER WORKING PAPER SERIES

REAL WAGES OVER THE BUSINESS CYCLE

Robert Barsky

Gary Solon

Working Paper No. 2888

NATIONAL BUREAU OF ECONOMIC RESEARCH

1050 Massachusetts Avenue

Cambridge, MA 02138

March 1989

This research has been supported by National Science Foundation Grant No. SES-8709217 and by an Alfred P. Sloan Research Fellowship awarded to Solon. The authors are grateful for the excellent research assistance of Deborah Laren and Robert Wood and for comments from John Bound, Charles Brown, Mary Corcoran, Edward Gramlich, Miles Kimball, and seminar participants at The University of Michigan, Harvard, Princeton, and the University of Rochester. The research reported here is part of NBER's research program in Economic Fluctuations. Any opinions expressed are those of the authors not those of the National Bureau of Economic Research. 
NBER Working Paper \#2888

March 1989

REAL WAGES OVER THE BUSINESS CYCLE

ABSTRACT

This paper is an examination of cyclical real wage behavior in the United States since World War II. Like most previous aggregate studies, ours finds little cyclicality in aggregate industry real wage data. On the other hand, our analysis of longitudinal microdata from the Panel Study of Income Dynamics reveals substantial procyclicality. We find that this procyclicality is obscured in industry average wage statistics, and to a lesser extent in economywide averages, because those statistics are constructed in a way. that gives greater weight to low-wage workers during expansions.

The almost complete absence of evidence for countercyclical real wages suggests that movements along labor demand curves have not played a dominant role in cyclical employment fluctuations over the last 40 years. Instead, the procyclicality of real wages indicates that cyclical employment fluctuations have been generated mainly by shifts in labor demand. The sources of these shifts and of the positive slope of the effective labor supply curve, however, remain open to alternative interpretations.

Robert Barsky

Graduate School of Business

University of Chicago

Chicago, IL 60637
Gary Solon

Department of Economics

The University of Michigan

Ann Arbor, MI 48109-1220 


\section{Real Wages over the Business Cycle}

"The older empirical work ... suggests a null hypothesis that real wages and employment are statistically independent over the business cycle. Our main empirical conclusion is that it is difficult to reject this hypothesis for the 12 countries studied (and, in particular, for the United States)."

- Geary and Kennan (1982, p. 855)

"I find real wages to be very procyclical. A percentage point rise in the unemployment rate is associated with a decrease in real wages of between 1.5 and 2 percent."

- Bils (1985. p. 668)

"These results suggest that recent data for the United States do offer support for the hypothesis of the countercyclical movement of the real wage rate."

- Chirinko (1980, p. 461)

Leading macroeconomists from Keynes on have discussed the movement of real wages over the business cycle. The cyclicality of real wages is of interest in its own right, but more importantly it plays a major role in many theoretical models of the business cycle. Consequently, dozens of empirical researchers have used evidence on real wage behavior as a means of testing alternative macroeconomic theories. As the quotations above suggest, the resulting studies have produced a bewildering array of seemingly conflicting findings. Many studies of industry-level time series data have concluded that real wages are noncyclical, but a few time series studies have claimed to demonstrate countercyclicality or procyclicality, and more recent studies of longitudinal microdata typically have produced evidence of procyclicality. Because the studies' methods differ in so many dimensions - choice of sample period, level of aggregation, price index, treatment of overtime pay, dynamic specification, etc. - it is far from obvious what generates the divergence of results. 
Our goal in this paper is to clarify the evidence on cyclical real wage behavior in the United States since World War II. Our approach is to conduct a wide variety of analyses motivated by a succession of alternative theories. In the process, we generate a broad-ranging body of evidence that enables us to view what produces variations in results and to assess whether our own results can be reconciled with each other and with results from preceding studies. At the same time, we rely on very simple econometric methods in order to make the sources of our results as transparent as possible. What emerges is a surprisingly coherent account of real wage cyclicality.

In Section I. we summarize macroeconomic theories that, on the basis of different varieties of nominal wage stickiness, predict countercyclical real wages. Then we test numerous variants of such theories with empirical analyses tailored to the particular theories. The results, basē mainly on industry time series data, show virtually no evidence of countercyclicality. In Section $\Pi$, we consider theories that, on the basis of labor demand shifts along positively sloped effective labor supply curves, predict procyclical real wages. There we supplement the time series evidence with analyses of longitudinal microdata from the Panel Study of Income Dynamics. The longitudinal analyses reveal substantial procyclicality of real wages. This procyclicality is obscured in the published aggregate wage data, especially the industry-level data, because those data are constructed in a way that gives greater weight to low-wage workers during expansions. We then interpret our procyclicality results in terms of the cyclical upgrading of workers across jobs. In Section II, we summarize our findings and their consistency with each other, with previous studies, and with economic theory.

\section{Are Real Wages Countercyclical?}

Simple versions of major business cycle theories frequently have predicted countercyclical real wages. The best-known example, of course, is the model in Chapter 2 of Keynes' General Theory (1936). In that model, what happens during a recession is that, due to downward rigidity in the nominal wage, the real wage sticks above the 
market-clearing level. Employment then is determined by the "short side" of the market (i.e., by labor demand), and low employment and high unemployment ensue. Keynes therefore predicted:

... with a given organisation, equipment and technique, real wages and the volume of output (and hence of employment) are uniquely correlated, so that, in general, an increase in employment can only occur to the accompaniment of a decline in the rate of real wages. Thus I am not disputing this vital fact which the classical economists have rightly asserted as indefeasible. [1936, p. 17]

Similar predictions appear in early versions of equilibrium business cycle models, in which cyclical employment fluctuations arise from workers' misperceptions of the general price level. Friedman's presidential address to the American Economic Association, for example, contains this description of the labor market during an expansion:

Because selling prices of products typically respond to an unanticipated rise in nominal demand faster than prices of factors of production. real wages received have gone down - though real wages anticipated by employees went up, since employees implicitly evaluated the wages offered at the earlier price level. Indeed, the simultaneous fall ex post in real wages to employers and rise ex ante in real wages to employees is what enabled employment to increase. [1968, p. 10]

Phelps introduction to the "Phelps volume" gives the corresponding description of a recession:

... the acceptance wage on each island will fall less than proportionally to product prices; some workers will refuse employment at the new (lower) market-clearing money wage rates, preferring to spend the time searching for a better relative money wage elsewhere. Effective labor supply thus shifts leftward at every real wage rate; real wage rates rise, and profit-maximizing output and employment fall. [1970. p. 7]

The common feature of the Keynes and Friedman-Phelps models is that, in both, cyclical employment fluctuations reflect movements along a labor demand curve induced by shifts in effective labor supply as a function of the real wage. The models differ mainly in their accounts of why the effective supply curve shifts.

Most of the many studies of post.World War II real wage data have failed to find countercyclical real wages. This has led numerous writers to tinker with the Keynes or Friedman-Phelps analyses, either to explain why real wages are not countercyclical or to 
explain why the countercyclicality is obscured in the data. The remainder of this section develops and applies a framework for evaluating each of these explanations.

\section{Econometric Specification}

A simple statistical model for exploring the cyclicality of real wages is

$$
\ln W_{t}=\gamma_{1}+\gamma_{2} t+\gamma_{3} t^{2}+\gamma_{4}\left(U_{t}-\delta_{1}-\delta_{2} t-\delta_{3} t^{2}\right)+\epsilon_{t}
$$

where $W_{t}$ is some aggregate real wage measure in year $t, U_{t}$ is the civilian unemployment rate, and $\epsilon_{t}$ is a random error term. A quadratic time trend is included in the wage equation, and the unemployment rate is entered as a deviation from its own quadratic trend, in order to focus on the cyclical components of wage and unemployment variation. A countercyclical real wage would be denoted by a positive value for $\gamma_{4}$, a procyclical real wage by a negative value.

First-differencing equation (1) yields the main equation for our aggregate time series analyses:

$$
\Delta \ln W_{t}=\beta_{1}+\beta_{2} t+\beta_{3} \Delta U_{t}+v_{t}
$$

where $v_{t}=\Delta \epsilon_{t}: \beta_{1}=\gamma_{2}-\gamma_{3}+\gamma_{4}\left(\delta_{3}-\delta_{2}\right), \beta_{2}=2\left(\gamma_{3}-\gamma_{4} \delta_{3}\right)$, and $\beta_{3}=\gamma_{4} \frac{\geq}{<} 0$ as the real wage is countercyclical, noncyclical, or procyclical. Equation (2) is precisely the same specification used by Bils (1985) in his aggregate time series analyses, which facilitates comparisons of our results to those of one of our closest forerunners. Another convenient feature of equation (2), reflected in the Durbin-Watson statistics in the tables below, is that the error term $v_{t}=\Delta \varepsilon_{t}$ usually displays little serial correlation. ${ }^{1}$ This result dovetails with the finding of numerous aggregate studies, such as Altonji and Ashenfelter (1980), that the stochastic behavior of the log real wage resembles a random walk. ${ }^{2}$

\footnotetext{
${ }^{1}$ In addition to the small first-order autocorrelations indicated by the Durbin-Watson statistics, correlograms of the OLS residuals display small autocorrelations at higher orders as well.

${ }^{2}$ We have experimented with estimating equation (2) without any time trend and with a quadratic time trend. These modifications have remarkably little effect on our estimates of $\beta_{3}$. We also have verified the robustness of our results to changes in cycle indicator, in
} 


\section{Preliminary Aggregate Analyses}

We begin with ordinary least squares estimation of equation (2) with highly aggregated annual time series data for 1947-48 to 1986-87. Following Bils (1985), we initially measure the real wage with average hourly earnings of production or nonsupervisory workers, deflated by the implicit GNP deflator. The earnings data are generated by the Bureau of Labor Statistics establishment survey. Details on data sources are provided in the Appendix.

The first row of Table 1 presents results for total private nonagricultural employment. The estimated coefficient of $\Delta \mathrm{U}_{\mathrm{t}}, \hat{B}_{3}=-.0026$, is slightly procyclical and of marginal statistical significance. It implies that. when the unemployment rate increases by an additional percentage point, real wage growth declines by about one-quarter of a percentage point. This estimated magnitude of procyclicality is only about one-fifth of that reported by Bils (1985). ${ }^{3}$

As Chirinko (1980) and Huizinga (1980) have pointed out, even this mild procyclicality might be an artifact of a composition bias in the aggregate data. The bias arises from a fact documented by Okun (1973) and easily confirmed by a perusal of employment tabulations by industry - that employment in certain high-wage industries,

particular, replacing $\Delta U_{t}$ with change in log real GNP or change in the log of the civilian employmentipopulation ratio. Finally, it is worth noting that the $t$-ratio for the relationship between $\Delta \ln W_{t}$ and $\Delta U_{t}$ is algebraically invariant to which variable is on the left side of the regression equation and which is on the right.

${ }^{3}$ Bils estimates $\hat{\mathcal{B}}_{3}=-.0120$ with aggregate data for $1966-67,1967-68,1968-69$, 1969-70, 1970-71, 1971-73. 1973-75, 1975-76, 1976-78, and 1978-80. Some of his observations are two-year differences to maintain consistency with his microdata from the National Longitudinal Surveys of labor market experience. We have replicated his analysis with a more recent revision of the implicit GNP deflator series and obtained a slightly smaller $\hat{\beta}_{3}=-.0104$. Filling in his missing years, i.e., using one-year differences for all years from 1966-67 to 1979-80, further reduces $\hat{\beta}_{3}$ to -.0085 . Extending the sample period to $1986-87$ produces $\hat{\beta}_{3}=-.0062$. Then extending the sample period back to $1947-48$ produces our estimate of -.0026 . Bils also reports an estimate of -.0108 based on only manufacturing industries. We have found that extending his manufacturing analysis to the period $1966-67$ to $1986-87$ reduces $\hat{\beta}_{3}$ to only -.0043 , and extending back to $1947-48$ produces $\hat{\beta}_{3}=-.0021$. Finally, for manufacturing wages excluding overtime, Bils estimates $\hat{\mathcal{B}}_{3}=-.0065$. Extending this analysis to the period 1966-67 to $1986-87$ produces $\hat{\beta}_{3}=-.0013$. Extending back to $1947-48$ yields $\hat{\beta}_{3}=.00002$. 
particularly durable goods manufacturing and construction, is especially sensitive to the business cycle. During a recession, therefore, the reduced employment shares of these industries produce a downward tendency in the economywide average wage. As a result, even if real wages were countercyclical in each industry, the economywide average might obscure that countercyclicality and might even appear procyclical.

The remainder of Table 1 begins to address that possibility by presenting separate results for each of nine major industry categories. The results indicate that disaggregating by major industry does tend to reduce the estimated procyclicality of real wages. Nevertheless, the most striking aspect of the major industry results is the absence of substantial countercyclicality in any industry'. These results are essentially an updated replication of a long history of studies that, contrary to the predictions of the Keynes and Friedman-Phelps models, have failed to discover countercyclical real wages. ${ }^{4}$ Proponents of the Keynes or Friedman-Phelps models have suggested a variety of explanations for this failure, which are discussed in turn below.

\section{Overtime Pay}

The share of overtime hours in total work hours increases during expansions, and these hours typically are compensated with a wage premium, often "time and a half." Lucas (1970) has argued that the procyclicality of the overtime share might account for the failure to observe countercyclicality in real average hourly earnings. Even if employment expansions are induced by declines in real base wages, it is possible. depending on the production function, for those base wage reductions to lead to such disproportionate increases in overtime hours that real average hourly earnings might increase.

A simple way to test this hypothesis is to reestimate equation (2) with a wage measure based on average hourly earnings excluding overtime. The first panel of Table 2

\footnotetext{
${ }^{4}$ See, for example, Bodkin (1969) and Geary and Kennan (1982).
} 
presents the results of such a reestimation for durables and nondurables manufacturing, the only major sectors for which straight-time and overtime hours data are separately available. Excluding overtime does move the estimates of $\beta_{3}$ in a countercyclical direction, as it must given the procyclicality of the overtime share. But the results still do not show significant countercyclicality in real base wages. Furthermore, results for more detailed industries, to be presented below, also fail to indicate a pattern of countercyclicality. One other indication that real base wages are not countercyclical is that, in Table 1 , countercyclicality does not appear even for sectors that make little use of overtime, particularly services and finance/insuranceireal estate. ${ }^{5}$

\section{Price Indexes}

As noted by Bodkin (1969) and Geary and Kennan (1982), if cyclical employment fluctuations are movements along a labor demand curve, the appropriate real wage measure is deflated by the relevant product price, not by a general consumer price index. Indeed, the only bit of evidence for real wage countercyclicality reported by Bodkin is for a wage measure deflated by a producer price index.

In the second panel of Table 2, we report the results that appear when average hourly earnings (excluding overtime) in durables and nondurables manufacturing are deflated by the producer price indexes (PPIs) for the respective sectors, instead of by the implicit GNP deflator. The estimate of $\beta_{3}$ for durables becomes slightly less countercyclical. The estimate for nondurables is more countercyclical, but is very imprecisely estimated. At this level of aggregation. then, deflating by PPIs produces no clear evidence of countercyclicality, but the greater volatility of the PPIs makes accurate estimation difficult. Further results based on PPIs for more detailed industries will be presented below:

${ }^{5}$ See Carr (1986, Table 2) for data on overtime by industry. 
For completeness, in the third panel, we report estimates based on the consumer price index (CPI). These are less countercyclical than those based on either of the other types of price index.

\section{Dynamic Specification}

Neftci (1978) and Sargent (1978) have argued that, if employment adjustment is costly, the relationship between real wage movements and movements in employment or unemployment is not contemporaneous as in equation (2); instead, the latter movements should lag the former. This raises the possibility that, once the dynamic nature of the employment-wage relationship is recognized, the data might be interpretable as lying along a labor demand curve after all. ${ }^{6}$ Bils $(1985)$ has argued that noncontemporaneous wageemployment relationships should be less of an issue with annual data than with the monthly and quarterly data used respectively by Neftci and Sargent. but it still seems worthwhile to check for dynamic relationships.

Our specification in equation (2) assumes that real wage growth is related to only the current and once-lagged unemployment rates and that the current and lagged rates enter with equal and opposite coefficients. The analysis reported in the first panel of Table 3 checks the equal-and-opposite restriction by including $U_{t-1}$ as well as $\Delta U_{t}$ in the regression, so that the relevant test is whether the coefficient of $U_{t-1}$ is zero. That restriction is clearly acceptable.

The reasoning of Neftci and Sargent suggests that current real wages might be related to future unemployment rates. The second and third panels of Table 3 check this possibility by entering first and second leads of the unemployment rate. The hypothesis of no relationship with future unemployment rates also is clearly acceptable. The estimatec coefficients of $\mathrm{U}_{t+1}$ in the second panel are small and statistically insignificant, and $F$.

${ }^{6}$ Neftci and Sargent both present evidence for lagged employment responses to real wage movements, but Geary and Kennan (1982) report that this finding can be overturnec either by extending the sample period or by deflating by a producer instead of consumer price index. 
tests of the hypothesis that $U_{t+1}$ and $U_{t+2}$ both have zero coefficients easily accept the hypothesis at any conventional significance level. ${ }^{7}$

\section{Sample Period}

The few studies that have claimed to find inklings of countercyclical real wages have been based on data from roughly the first half of our sample period. On the other hand, more recent studies based on microdata from roughly the second half of our sample period usually have found procyclical real wages. Some writers, such as Coleman (1984) and Kniesner and Goldsmith (1987), have attributed the supposedly different pattern in the second period to the special role of oil price shocks in recent recessions. It therefore seems worthwhile to examine wage cyclicality in particular subperiods.

The first panel of Table 4 presents results for 1947-48 to 1966-67. Including observations from only the first half of the sample period does move the results in a countercyclical direction, but the estimated countercyclicality is not substantial. The tratio for nondurables is the largest yet and is still of only marginal statistical significance. The results for the second half of the sample period, shown in the second panel, are remarkably noncyclical. Although differences in sample period can account for some of the discrepancy between time series studies and microdata studies, we will argue in Section II that a composition bias in the time series data is a more important factor.

\section{Multisector Models}

The crucial role of nominal wage rigidity in the original Keynesian model implies a prediction of countercyclicality in aggregate real wages. The apparent absence of such countercyclicality, among other things, has motivated some researchers to develop multisector models in which some parts of the labor market are characterized by Keynesian wage rigidity and others are not. Hall (1975), for example, has suggested that

\footnotetext{
${ }^{7}$ We obtain similar results when we reverse the regression and test for the dependence of $\Delta U_{t}$ on lagged wage variables.
} 
the Keynesian sector is comprised of "nonentrepreneurial" employers that are relativel insulated from product market competition while the flexible-wage sector is inhabited b. "entrepreneurial" employers. Raisian (1979) has described a similar model except that hi sectors are distinguished by unionization instead of entrepreneurial status. In thes models, it is possible for nominal wage rigidity in the Keynesian sector to generate cyclica employment fluctuations, but for the countercyclicality of real wages in the Keynesia sector to be masked in the economyxide data.

The results in Table 1 present an immediate challenge to such theories. I different industries are supposed to have very different cyclical wage patterns, why do al the major industries in Table 1 display so little real wage cyclicality? There is littl indication in Table 1 that less entrepreneurial industries (e.g., transportation and publi utilities) display greater nominal wage rigidity and more countercyclical real wages. No is there much indication of that sort for more unionized industries (e.g., manufacturing mining, and transportation and public utilities). ${ }^{8}$

To investigate sectoral differences in finer detail, we have estimated equation (2 for fifteen detailed manufacturing industries for which all the necessary data ar available. $^{9}$ The second and third panels of Table 5 present results for average hourl: earnings (excluding overtime) deflated respectively by the implicit GNP deflator and thr consumer price index. Once again, there is little indication of regular cyclical patterns it the purchasing power of hourly wages - most of the estimated coefficients are small an statistically insignificant. More importantly, there is little evidence for the particula: patterns predicted by the multisector theories. If one takes a very high four-firn

\footnotetext{
${ }^{8}$ Hall's evidence of interindustry differences in wage cyclicality is based on an annua earnings measure that appears to confound hourly wage cyclicality with some portion 0 the interindustry variation in hours cyclicality. Raisian's evidence of union-nonunios differences is based on microdata for only 1967-74. Furthermore, his business cycl indicator, the deviation of the annual unemployment rate in the individual's industry fron its 1967-74 average, may reflect sectoral trends as well as cyclical fluctuations.

${ }^{9}$ These analyses are based on shorter sample periods because of the limited availability 0 the necessary industry PPIs and wage measures (excluding overtime).
} 
concentration ratio as indicative of insulation from product market competition, one might expect highly concentrated industries to display countercyclical real wages. On the contrary, tobacco manufactures, rubber and miscellaneous plastics products, household appliances, and motor vehicles and equipment display strikingly noncyclical real wages. Furthermore, this noncyclicality appears despite high unionization in all four of these industries. ${ }^{10}$ Nor is there especially strong evidence for countercyclicality in other highly unionized, but less concentrated industries (e.g., paper and allied products, cementhydraulic, and blast furnaces and steel mills). Additional evidence based on microdata, to be presented in Section II, also fails to corroborate a union-nonunion difference in wage cyclicality. ${ }^{11}$

The last panel of Table 5 presents results based on defiating wages by industryspecific PPIs instead of by general price indexes. The resulting coefficient estimates become larger in magnitude, but diverge from zero in different directions for different industries. It is important to recognize that the changes in results from the earlier panels to the last must reflect interindustry differences in the cyclicality of relative product prices, not in the cyclicality of the purchasing power of workers' wages. Indeed, one can infer the direction of cyclicality of relative product prices by observing the sign of the change in coefficient estimates from the earlier panels to the last. ${ }^{12}$ It is noticeable that, with the exception of lumber and wood products, the only industries in the table estimated to have procyclical relative prices are unconcentrated nondurables industries - dairy products, men's and boys' shirts and nightwear, and footwear except rubber. In accordance with a hypothesis in Domowitz, Hubbard, and Petersen (1988), durable goods industries show a

\footnotetext{
${ }^{10}$ See Freeman and Medoff (1979) for unionization rates by industry.

${ }^{11}$ Pencavel and Hartsog's (1984) time series study also fails to find clear-cut evidence for a countercyclical union-nonunion wage gap.

${ }^{12}$ The last panel gives estimates of $\Delta \ln \left(\mathrm{N}_{\mathrm{it}} / \mathrm{P}_{\mathrm{it}}\right)$ associated with an unemployment rate change, where $N_{\text {it }}$ is the ${ }^{i t h}$ industry's nominal wage and $P_{i t}$ is its PPI. The earlier panels give estimates of $\Delta \ln \left(N_{i t} P_{t}\right)$, where $P_{t}$ is a general price index. The difference between these two expressions is simply the change in the log of the relative product price $\mathrm{P}_{\text {it }} / \mathrm{P}_{\mathrm{t}}$.
} 
pronounced tendency toward countercyclicality in relative product prices. The sam applies for concentrated industries, including those in the nondurables sector (tobacc manufactures, chemicals and allied products, and rubber and miscellaneous plastic: products). This is consistent with Rotemberg and Saloner's (1986) hypothesis tha oligopolistic industries tend to enter price wars during expansions.

Finally, the results in Table 5 are informative about one other Keynesiar explanation of the apparent noncyclicality of real wages - that, although nominal rigidity plays a key role in cyclical employment fluctuations, fixed markups of product prices over wage costs might maintain noncyclicality in the wage/price ratio. Hall and Taylor (1986 p. 395), for example, note the apparent noncyclicality of real wages and then claim. "This stability is a reflection of the markup pricing strategies." The trouble with this explanation is that it implies noncyclicality, not in the purchasing power of workers' wages by industry, but in workers' own-product wages. One could just as well read Table 5 however, to suggest that, although the purchasing power of industry wages shows little cyclicality, the markup of product prices over wages does vary cyclically in different ways for different industries.

\section{Summary}

Our analysis of U.S. post-World War II time series data has accumulated c preponderance of evidence that industry real uages, relative to general price indexes appear more or less noncyclical (aithough industry product wages may follow various cyclical patterns due to cyclicality in relative product prices). We have found hardly a shred of evidence to support either the original or modified versions of either the Keynes ot Friedman-Phelps theories of cyclical employment fluctuations as a consequence of nomina wage stickiness. Our evidence against real wage countercyclicality will be strengthened b! our finding in the next section that the industry time series data are subject to a sizable countercyclical bias. 
These findings in no way deny that labor demand curves slope downward or that unanticipated price shocks ever shift employment along labor demand curves in industries with nominally rigid wages. ${ }^{13}$ What they do deny is that such shifts have played a dominant role in cyclical employment movements in the U.S. over the last 40 years.

\section{Are Real Wages Procyclical?}

Theories that predict countercyclical real wages interpret cyclical employment fluctuations as the consequence of shifts in effective labor supply. Theories based instead on shifts in labor demand predict procyclical real wages. These shifts in labor demand might arise either from technological or other productivity innovations, as in real business cycle models, or from changes in output demand induced by nominal disturbances, as in some Keynesian and monetarist models.

In either case, employment expansions resulting from labor demand shifts should be associated with rises in real average hourly earnings. At the intensive margin, the employment increase typically is comprised partly of an increase in overtime hours, which command a wage premium. At the extensive margin, employers should bid up the real base wage as they attempt to attract additional workers. These efforts will lead to an increase in aggregate employment only if the short-run aggregate labor supply function is positively sloped. Lucas and Rapping's (1969) model of intertemporal substitution in labor supply provides a theoretical basis for expecting the slope of the short-run labor supply curve to be positive. ${ }^{14}$ If it is, a rightward shift in the labor demand function leads to increases in both employment and the real wage. Thus, for example, in Barro and King's intertemporal substitution model:

\footnotetext{
${ }^{13}$ Card (1988) finds evidence for such shifts in data on unionized Canadian employers.

${ }^{14}$ As Hall (1988) notes, efficiency wage models give an alternative basis for a positively sloped effective labor supply curve. One can characterize those models as having relabeled the positively sloped curve in the wage-employment diagram as a "no-shirking condition."
} 
... the real wage, which equals the marginal product of labor, must rise along with the increases in output and work effort. In other words, a procyclical pattern for the real wage is central to our theoretical analysis. [1984, p. 833]

Of course, the theoretical prediction of procyclicality in real wages seems to be at odds with much empirical evidence of noncyclicality, including the results presented in Section I. In response, some writers, including Barro and King (1984, p. 833) and Lucas (1977, p. 17), have attempted to explain the apparent noncyclicality of real wages by reference to implicit contract theories of real wage smoothing in long-term employment relationships. This might be an adequate explanation if most of the cyclical variation in employment and unemployment were at the quasi-intensive margin of temporarily laying off and recalling workers with permanent attachments to their employers. But the strong procyclicality of new hire rates and the predominant role of permanent layoffs in cyclical unemployment suggest that a large portion of cyclical employment variation occurs at the extensive margin. ${ }^{15}$ The point remains that employers should have to offer higher real wages during an expansion to attract more new workers.

A second explanation, suggested by Stockman (1983), is that the aggregate time series data contain a countercyclical composition bias that obscures the true procyclicality of real wages. The published aggregate data on average hourly earnings are constructed by dividing total payroll by total hours; i.e., they are of the form

$$
\begin{aligned}
\mathrm{w}_{t} & =\sum_{i=1}^{N} \mathrm{H}_{i t} \mathrm{w}_{i t} / \mathrm{H}_{t} \\
& =\sum_{i=1}^{N}\left(\mathrm{H}_{i t} / \mathrm{H}_{\mathrm{t}}\right) \mathrm{w}_{i t}
\end{aligned}
$$

where $i$ indexes individual workers, $H_{i t}$ is the $i^{\text {th }}$ worker's hours of work in year $t, W_{i t}$ is the $i^{\text {th }}$ worker's average hourly earnings, and $H_{t}=\sum_{i=1}^{N} H_{i t}$. As the second version of equation (3) makes clear, the published aggregate average hourly earnings variables are

\footnotetext{
${ }^{15}$ See Lilien and Hall (1986).
} 
weighted averages of individuals' average hourly earnings, where the weights are the individuals' shares of total work hours. If the hours shares of high-and low-wage workers vary cyclically, this will induce a compositional cyclicality in the aggregate wage measure that is unrelated to the cyclical wage variation faced by individual workers. In particular, Clark and Summers (1981), Okun (1973), Mitchell, Wallace, and Warner (1985), and Kydland (1984), among others, have documented the greater cyclical sensitivity of employment for workers in low-wage demographic groups and education categories. Thus, low-wage workers tend to receive less weight in economywide aggregate wage data during a recession and more during an expansion. Moreover, if there is countercyclicality in worker quality by industry. as is also documented by Okun, a similar compositional effect applies $w$ industry aggregate wage measures. Because these compositional effects bias aggregate wage measures in a countercyclical direction, they might account for the weakness of the evidence for procyclicality in aggregate wage data.

To avoid the composition bias in aggregate data, several researchers, including Stockman (1983) and Bils (1985), have reexamined the cyclicality of real wages with microdata from longitudinal surveys. ${ }^{16}$ With such data, it becomes possible to investigate cyclical patterns in individuals' real wages and therefore to avoid the obfuscating factor of composition changes. In accordance with Stockman's conjecture, most studies following this strategy have found strong evidence of procyclicality in real wages. In the remainder of this section, we imitate this strategy with a new analysis of microdata from the Panel Study of Income Dynamics, and we then proceed to explore the labor market processes underlying the divergences between the evidence from microdata and aggregate data.

\section{Description of Data}

Our microdata come from the Panel Study of Income Dynamics (PSID), a longitudinal survey that has collected data on members of the same families every year

${ }^{16}$ Other studies of this type include Coleman (1984), Mather (1987), and Keane, Moffitt, and Runkle (1988). 
since 1968. Our sample is drawn from the PSID's 1985 cross-year family-individual response file. We restrict our sample to male household heads born between 1925 and 1942 who reported positive annual hours of work and labor income for every year from 1967 to 1984 . (The hours and income questions pertain to the calendar year preceding the interview. The birth year restriction assures that the sample members are between the ages of 25 and 59 throughout the sample period.) We exclude the Survey of Economic Opportunity portion of the PSID, which overrepresents the low-income population. ${ }^{17}$ The resulting sample contains 18 years of data for each of 357 men. Our measure of an individual's hourly wage rate in a given year is simply the ratio of his annual labor income to his annual hours of work. A more detailed data description is provided in the Appendix.

\section{Preliminary Analyses}

For comparison purposes, we begin with some results based on Section I's aggregate wage data from the Bureau of Labor Statistics (BLS) establishment survey. In the first panel of Table 6 , we rewrite the estimates of $\hat{B}_{3}$ from the first three rows of Tabie 1. These are the coefficient estimates for $\Delta U_{t}$ from the regressions in which the dependent variables are the changes in the log payrollhours ratios for durable goods manufacturing, nondurable goods manufacturing, and total private nonagricultural employment from 1947-48 to 1986-87. Then, for temporal comparability with our PSID data, in the second panel we report the results from reestimating these regressions with the BLS data for 1967-68 to 1983-84. The BLS results in Table 6 recall two points from Section I. First, as in Table 4, restricting the sample period to more recent years moves the results in a procyclical direction. Second, the total private nonagricuitural wage measure displays more procyclicality than do the industry-specific measures because of the procyclicality in the employment shares of the high-paying durable goods manufacturing

\footnotetext{
${ }^{17}$ We also have experimented with excluding men that were exclusively self-employed in any year and have found that this exclusion has virtually no effect on the results reported below.
} 
and construction sectors. In the context of Section I's analysis of theories in which cyclical employment fluctuations represent movements along negatively sloped industry labor demand curves, this aggregation effect threatened to obscure the real wage countercyclicality we were attempting to verify. But, in the context of the present section, in which we are assessing theories involving employment variations along positively sloped labor supply curves, the greater opportunities workers have during expansions to upgrade into higher-paying industries comprise a genuine form of procyclicality in workers' real wages. In this setting, then, the broader wage measure is the more revealing statistic.

Nevertheless, even the total private nonagricultural payrollhours ratio is an hours-weighted average of individuals' wages and is susceptible to Stockman's countercyclical composition bias. ${ }^{18}$ In contrast, our PSID data, which follow the same prime-age men over time, enable the construction of wage measures free of such bias. Simply restricting the sample to prime-age men avoids bias from cyclical changes in the hours shares of non-prime-age and female workers. Furthermore, access to data on individuals wages permits the calculation of unueighted averages of the individuals' wages.

Indeed, reestimating equation (2) with the PSID data does produce dramatically more procyclical estimates. As shown in the fourth row of Table 6, using the unweighted average of the sample individuals' log wages more than doubles the estimated coefficient of $\Delta U_{t}$ to $\hat{\beta}_{3}=-.0126$. To check that this increase in estimated procyclicality comes from avoiding composition bias, rather than from using the average of a log instead of the log of an average, in the fifth row we use the log of the unweighted average wage. This raises the estimated procyclicality still further to $\hat{\beta}_{3}=-.0137$. Table 7 , which displays our PSID sample's average log real wages and log average real wages by year, clarifies the basis of our regression results. Examination of the table makes plain that real wage growth was unusually low in recession years.

\footnotetext{
${ }^{18}$ In addition, the BLS measures are restricted to production or nonsupervisory workers and therefore do not capture procyclicality in opportunities to advance out of production and nonsupervisory jobs.
} 
To highlight the importance of the hours-weighting issue, in the last row of Table 6 we report the results of a mischievous exercise. We inject a composition bias into our PSID data by calculating the ratio of total earnings to total hours in our sample; that is, we deliberately compute an hours-weighted average wage similar in construction to the BLS measures. Although our PSID version of this variable is still free of composition bias from cyclicality in the hours shares of non-prime-age and female workers, introducing hours-weighting among the prime-age men in our sample dramatically reduces $\hat{\beta}_{3}$ to -.0078 . Because both the weighted and unweighted estimates of $\beta_{3}$ are based on the same individual observations, the discrepancy between the estimates arises entirely from the differential cyclicality of hours between high-wage and low-wage workers. Indeed, the result in equation (9) of Bils (1985) shows that 100 times this discrepancy directly estimates the proportional shortfall of the average wage for a cyclically marginal hour relative to the average wage for an hour that is worked regardless of the stage of the business cycle. Our results therefore imply that, among prime-age men, cyclically marginal hours are paid at only about half the rate of nonmarginal hours. ${ }^{19}$ Bils reports a smaller shortfall, about 20 percent, among the very young men in his sample.

A simple method for interpreting the magnitude of our estimates of $\beta_{3}$ is based on the observation that $\Delta U_{t}$ is a slightly damped approximation for 100 times the negative change in the $\log$ of the employment/population ratio. ${ }^{20}$ Hence, $-100 \hat{\beta}_{3}$ can be regarded as a crude estimate of the inverse elasticity of the short-run aggregate labor supply curve. Our estimate in the fourth row of Table $6, \hat{\beta}_{3}=-.0126$, therefore implies a labor supply elasticity of $1 / 1.26=.79$. Similarly, in the regression with $\Delta U_{t}$ on the left side of the equation and $\Delta \ln \mathrm{W}_{\mathrm{t}}$ on the right, the estimated coefficient of $\Delta \ln \mathrm{W}_{\mathrm{t}}$ divided by 100 can be regarded as a crude estimate of the labor supply elasticity itself. Least squares

\footnotetext{
${ }^{19}$ A very similar result is reported in Prescott $(1986$, p. 32$)$.

${ }^{20}$ The damping arises from the moderate procyclicality of the labor force participation rate. Change in log employment, in turn, is a damped version of change in log hours.
} 
estimation of this reversed regression produces an estimated labor supply elasticity of $.37 .^{21}$ Thus, given the degree of real wage procyclicality we have estimated, it is possible to rationalize observed cyclical employment fluctuations as labor supply responses to cyclical wage movements on the basis of short-run labor supply elasticities less than unity. Nevertheless, in Section III, we will question whether this is a completely satisfactory interpretation of the data.

It may be worthwhile to compare our results to those of Bils (1985), whose study of microdata from the National Longitudinal Survey (NLS) of young men also was motivated by the Stockman hypothesis that aggregate real wage data are contaminated by cyclical changes in the composition of the work force. Although Bils' evidence from microdata suggests strong procyclicality in real wages, so does his evidence from aggregate hours-weighted measures. He therefore concludes that composition bias is relatively unimportant. ${ }^{22}$ In footnote 2, however, we have demonstrated that Bils' unusual finding of strong procyclicality in aggregate real wage measures is an artifact of the particular ten observations he uses. Nevertheless, we have found that, even in a more typical period with less procyclicality in aggregate real wage measures, the microdata still display a statistically and substantively significant degree of procyclicality.

\section{Sample Selection Bias}

Before proceeding to more detailed analyses, we need to address the question of whether our results are somehow a spurious reflection of our sample selection criteria. In particular, one might reasonably be concerned about the restriction of our sample to men

${ }^{21}$ Leamer (1981) discusses conditions under which the probability limits of the two elasticity estimators bound the true elasticity. Using change in the log of the employment/ population ratio in place of $\Delta \mathrm{U}_{\mathrm{t}}$ changes the estimates .79 and .37 respectively to 1.05 and .46.

${ }^{22}$ See, in particular, page 684 of Bils' article. Similarly, the survey article by Kniesner and Goldsmith (1987, p. 1257) declares that "sample composition effects are empirically unimportant for this issue." In fact, although Bils' estimates from aggregate BLS data are strongly procyclical, his estimates from NLS microdata are substantially more so. 
employed in all 18 years of the sample period. Such a concern about the endogeneity of employment status has led Bils (1985) and Keane, Moffitt, and Runkle (1988) to attempt elaborate corrections for sample selection bias.

There are two reasons why we doubt the importance of sample selection bias in our own analysis. First, our wage measure is an annual average, unlike the NLS point-intime ineasures used by Bils and by Keane, Moffitt, and Runkle. Therefore, to be excluded from our sample because of nonemployment. an individual must be nonemployed for an entire calendar year. For the prime-age male population analyzed in our study, nonemployment for an entire calendar year is a considerably less likely occurrence than nonemployment in a particular reference week. ${ }^{23}$

Second, we have been unable to concoct a plausible structural model that would account for spuriously procyclical real wage patterns. For example, if one believes that periods of prolonged nonemployment reflect labor supply responses to transitorily low real wage opportunities, then our exclusion of such observations would bias our analysis toward understating the procyclicality of real wages. On the other hand, if one believes any of the sticky-nominal-wage theories tested in Section I, our exclusion of individuals unemployed because their real wages were too high would bias our analysis in the procyclical direction of understating the true countercyclicality of real wages. But, setting aside the almost complete absence of evidence for such theories, these theories still do not explain why the individuals remaining in our sample display strongly procyclical real wages.

\section{Detailed Analyses}

To facilitate more detailed analyses of the PSID data, we adopt the following statistical model for individuals' real wage rates:

$$
\ln W_{i t}=\gamma_{1}+\gamma_{2} t+\gamma_{3} t^{2}+\gamma_{4}\left(U_{t}-\delta_{1}-\delta_{2} t-\delta_{3} t^{2}\right)+\gamma_{5} Z_{i}+\gamma_{6} X_{i t}+\gamma_{7} X_{i t}{ }^{2}+\epsilon_{i t}
$$

${ }^{23}$ In total, 83 men are excluded from our sample because they had zero earnings in some year. The zero-earnings observations appear to arise mainly from disability, retirement, and nonpositive income from self-employment, rather than from unemployment. 
where $W_{i t}$ is the $i^{\text {th }}$ worker's real wage in year $t, U_{t}$ again is the civilian unemployment rate, $\mathrm{Z}_{\mathrm{i}}$ is a vector of time-invariant worker characteristics such as race and years of education, $X_{i t}$ is the worker's years of work experience as of year $t$, and $\epsilon_{i t}$ is a random error term. Equation (4) extends the standard log earnings function, popularized by Mincer (1974), to incorporate the general time trend and business cycle regressors from equation (1). First-differencing equation (4) yields

$$
\Delta \ln \mathrm{W}_{\mathrm{it}}=\beta_{1}+\beta_{2} \mathrm{t}+\beta_{3} \Delta \mathrm{U}_{\mathrm{t}}+\beta_{4} \mathrm{X}_{\mathrm{it}}+\mathrm{v}_{\mathrm{it}}
$$

where $v_{i t}=\Delta \epsilon_{i t}, \beta_{2}=2\left(\gamma_{3}-\gamma_{4} \delta_{3}\right)$ as in equation (2), $\beta_{1}=\gamma_{2}-\gamma_{3}+\gamma_{4}\left(\delta_{3}-\delta_{2}\right)+\gamma_{6}-\gamma_{7}$ encompasses real wage growth due to the accumulation of individual experience as well as general time trends, $\beta_{4}=2 \gamma_{7}<0$ reflects the concavity of the log wage/experience profile. and again $B_{3}=\nu_{4} \geq 0$ as the real wage is countercyclical, noncyclical, or procyclical.

First, we perform ordinary least squares estimation of equation (5) with our sample of 6,069 PSID observations (17 year-to-year changes for each of 357 men). The resulting coefficient estimate for $\Delta \mathrm{U}_{\mathrm{t}}, \hat{\beta}_{3}=-.0126$, is shown in the first column of Table 8. This estimate is identical to the one based on the aggregated PSID log wage data, as reported in the fourth row of Table 6 . The two estimates are necessarily equal because the only regressor in equation (5) that varies cross-sectionally, the work experience variable $\mathrm{X}_{\mathrm{it}}$, is perfectly correlated in the intertemporal dimension with $t$. Consequently, the only difference between the two regressions is that the time variable in the aggregate regression picks up both the general time effect and the effect of the aging of the sample cohort.

It is important to note, though, that the standard error estimate in Table 8 is only .0031 , as compared to .0036 in Table 6 . The estimate in Table 8 is biased downward by its neglect of the cross-sectional and serial dependence of the error term $v_{i t}$. As discussed by Coleman (1986), $v_{i t}$ is cross-sectionally correlated because different workers' error terms share common time effects. In addition, an analysis of serial correlation in the OLS residuals estimates that $v_{i t}$ ' which is the first difference of $\epsilon_{i t}$, has a first-order 
autocorrelation of -.39 and higher-order autocorrelations close to zero. ${ }^{24}$ Accounting for both types of dependence in $v_{i t}$ would require a complicated generalized least squares procedure, which we have not undertaken. Instead, we merely emphasize that, based on the comparison of corresponding results in Tables 6 and 8, the standard error estimates in Table 8 appear to be biased downward by about 15 percent.

Our first detailed analysis returns to the question of whether union wages are less procyclical than nonunion wages, as discussed in Section I. Here we add to equation (4) a dummy variable that equals 1 if the worker is a union member in the relevant year along with interactions of that variable with time, time squared, and the unemployment rate variable. Then we estimate the first-differenced form of the expanded equation. The coefficient of $\Delta \mathrm{U}_{\mathrm{t}}$ reflects the cyclicality of the real wage for nonunion workers, and the coefficient of the change in the interaction of the unemployment rate with the union dummy reflects the incremental cyclicality for union workers. As shown in the second column of Table 8, the estimated coefficient of $\Delta \mathrm{U}_{\mathrm{t}}$ is -.0114 for nonunion workers and $-.0114-.0052=-.0166$ for union workers. Thus, real wages are estimated to be more procyclical for union workers, but, as indicated by the small t-ratio for the interaction term, the estimated union-nonunion contrast is statistically insignificant. In short, the PSW microdata, like the aggregate data in Section I, provide no support for the hypothesis of a countercyclical union-nonunion wage gap.

Another important contrast is between workers that change employers and those that do not. Bils (1985) reports that the strong real wage procyclicality that he finds in his sample of young men from the NLS is heavily concentrated among those that change employers. Replicating his analysis with the PSID is problematic because the various definitions of job tenure used in the PSID over the years make it difficult to infer who

\footnotetext{
${ }^{24}$ Similar results are reported in MaCurdy (1982) and Topel (1987). The negligible higherorder autocorrelations support the omission of individual-specific intercepts from equation toward positive autocorrelations at all lags.
} 
changed employers when. Nevertheless, we try two approaches. First, because of the well-known large difference in employer attachment between young and mature men, ${ }^{25}$ we simply add to equation (5) an interaction of the change in the unemployment rate with a dummy variable that equals 1 when the worker is at least 35 years old. ${ }^{26}$ If real wage procyclicality is concentrated among employer-changers, one might expect less procyclicality for the older workers. As shown in the third column of Table 8, the older workers are estimated to have slightly less procyclical real wages, but the estimated difference is small and statistically insignificant.

Second, we borrow the complex algorithm described in Appendix 2 of Altonji and Shakotko (1985) that uses the various tenure variables in the PSID to impute tenure with employer for every year. ${ }^{27}$ Then we adopt a very conservative standard for classifying a worker as a "stayer" - he is counted as having stayed with the same employer between years $t-1$ and $t$ if his employer tenure variable equals at least 1 year in $t-1$, at least 1.5 in $t$, and at least 2 in $t+1$. Having assured that those classified as "stayers" almost certainly are true stayers, we then create a dummy variable that equals 0 for those classified as "stayers" and 1 otherwise. We loosely refer to those with a dummy value of 1 as "changers," but really they are "not-necessarily-stayers." We add this dummy variable and its interaction with change in the unemployment rate to equation (5). The coefficient of $\Delta U_{t}$ then reflects the cyclicality of the real wage for "stayers," and the coefficient of the interaction term reflects the incremental cyclicality for "changers." As shown in the fourth column of Table 8 , the estimated real wage procyclicality for "stayers" is nearly identical to that for the full sample, and the additional procyclicality estimated for "changers" is small and statistically insignificant.

\footnotetext{
${ }^{25}$ See Hall (1982), especially Table 7.
}

${ }^{26}$ More precisely, the dummy variable equals 1 for the year-to-year change from $t-1$ to $t$ if $\mathrm{t}$ minus the worker's birth year is at least 35 .

${ }^{27}$ We thank Joseph Altonji for his extraordinary helpfulness in sharing this algorithm. 
Thus, neither of our approaches to this issue substantiates the hypothesis that real wages are less procyclical for workers that stay with the same employer. In the next subsection, we suggest an interpretation that accounts for this discrepancy between our findings and Bils', as well as for many other patterns in our results.

\section{An Interpretation}

Our empirical analysis has found that (1) industry average real wages are more or less noncyclical, while economywide average real wages are moderately procyclical, (2) individual workers' real wages are decidedly procyclical, and (3) the procyclicality of real wages is about as pronounced for workers that stay with the same employer as for workers that do not. Here we attempt a description of wage and employment determination that is consistent with all three findings.

The starting point is that firms' real wage structures are sticky. Over the years, many observers of employer practices - such as Reder (1955), Hildebrand (1963), Doeringer and Piore (1971), and Hall (1974) - have commented on the apparent reluctance of employers to adjust their wage structures in response to short-term demand fluctuations, even when they do adjust their employment levels. This phenomenon, of course, is the empirical premise of the theoretical literature on implicit contracts. ${ }^{28}$ These same observers, however, have noted an additional phenomenon not reflected in the implicit contracts literature - that employers typically implement employment changes, beyond those accomplished by temporary layoffs and recalls, through adjustments in hiring and promotion standards. For example, in Reder's words:

${ }^{28} \mathrm{Hart}$ 's survey of that literature begins:

The theory of implicit contracts ... was developed in order to explain the observation that cyclical fluctuations in output are associated with large amounts of employment variability and only small amounts of (real) wage variability. The theory is based on the idea that it is optimal for less risk-averse firms to insure more risk-averse workers against fluctuations in the marginal (revenue) product of labour by offering them a sticky (real) wage. [1983, p. 3] 
Quality variations in labor markets arise through upgrading and downgrading of members of the labor force relative to the jobs they are to fill. When applicants become scarce, employers tend to lower the minimum standards upon which they insist as a condition for hiring a worker to fill a particular job - and vice versa when applicants become plentiful. [1955, p. 834]

In Hall's more formalistic language:

... suppose that there are $M$ grades of workers, indexed by $i$, and $N$ categories of jobs, indexed by $j$. Then $I$ define $c(j)$ as the grade of worker having a comparative advantage in job category $j$....

... The scale wage is determined bureaucratically. If it is set correctly, workers with a comparative advantage in category $j$ are hired into it, and the effective wage is the same as the scale wage. If the labor market is unexpectedly tight, workers hired into job $j$ will be of lower grade than $c(j)$, but they will be paid the scale wage for job $j$. The effective wage will exceed the scale wage as a consequence of the upgrading of the labor force within the job structure. In unexpectedly slack markets the opposite happens and the effective wage falls short of the scale wage. Mobility brings about movements in the effective cost of labor in the short run even though the scale wage is rigid. [1974, pp. 348-49]

This account of how employers respond to short-term fluctuations has received little attention in the recent theoretical literature, although Okun (1981) gives an informal discussion. Nor has it received a rigorous empirical treatment. Nevertheless, it is remarkably consistent with all of our empirical findings. If the firms in an industry do not adjust their real wage structures over the business cycle (and if the proportional allocation of employment between upper- and lower-level jobs is not markedly cyclical), then average real wages by industry will be approximately noncyclical. ${ }^{29}$ At the same time, the previously-noted procyclicality of the employment shares of durable goods manufacturing and construction will produce some procyclicality in the economywide average real wage. Furthermore, the procyclicality in workers' opportunities to upgrade to better jobs, both within firms and across firms and industries, will cause individual workers' real wages to be substantially procyclical. Finally, if many of the upgrading opportunities are within firms, this procyclicality will pertain to workers that stay with the same employer as well as to changers.

${ }^{29}$ The same argument applies to average industry wages over the seasonal cycle. Indeed, Barsky and Miron (forthcoming) find little seasonal cyclicality in the average real wage in manufacturing. 
To illustrate the argument more concretely, consider the simple example in Taole 9. One hundred potential workers are employed in either a high-wage or low-wage industry or are not employed. In the initial period, 40 workers are employed in the hignwage industry and are evenly divided between a $\$ 12$-an-hour entry-level job and a $\$ 20$ job. Another 40 are in the low-wage industry, evenly divided between a $\$ 6$ entry-level job and a $\$ 10$ job. The other 20 are not employed. The average wage in the high-wage industry is $\$ 16$, the average in the low-wage industry is $\$ 8$, and the average for all 80 employed workers is $\$ 12$.

In the expansion period, employers in the high-wage industry increase employment in both their job levels by $10 \%$, while employers in the low-wage industry increase employment in both their job levels by 5\%. The different growth rates are intended to represent the greater cyclical sensitivity of employment in certain high-wage industries, as discussed earlier. Neither industry's employers change real wages at any job level. Instead, in accordance with the upgrading process described above, they merely adjust their promotion and hiring rates. In particular, the high-wage industry fills the two new $\$ 20$ openings by promoting two workers from the $\$ 12$ level, and then fills the four openings at the $\$ 12$ level (including the two vacancies resulting from the promotions) by hiring four new workers away from $\$ 10$ jobs in the low-wage industry. In turn, the lowwage industry fills its five $\$ 10$ openings (including the four vacancies resulting from departures to the other industry) by promotion from the $\$ 6$ level, and hires six new workers at the $\$ 6$ level from the ranks of the nonemployed.

This stylized example of cyclical upgrading exhibits the main empirical features of real wage cyclicality. First, average real wages are noncyclical in both industries, remaining respectively at $\$ 16$ and $\$ 8$ (though, as noted in the Hall quotation, effective - i.e., worker-quality-adjusted - real wages would be procyclical). Because of the increased employment share of the high-wage industry, however, the economywide average wage has increased from $\$ 12$ to $\$ 12.09$. This, of course, corresponds to the 
moderate procyclicality observed in the aggregate wage data for total private nonagricultural employment.

Second, because of the promotion opportunities both within and between industries, individual workers' wages are quite procyclical. Among the 80 workers employed in the initial period, the average wage has grown from $\$ 12$ to $\$ 12.55$. At the same time, six workers previously not employed have been attracted to $\$ 6$ jobs. Of course, it is the averaging-in of these new low-wage workers that produces Stockman's countercyclical composition bias in the economywide average wage.

Finally, the procyclicality of individual workers' real wages is not confined to workers that change emplovers. Stavers' real wages also are procyclical because their chances of promotion are better during an expansion. It is natural that this procyclicality of stayers' real wages would be most evident in a data set such as ours, which is dominated by prime-age men. These workers typically have established matches with their long-term employers and achieve most of their career advances within furms. In contrast, for workers new to the labor market, such as Bils' sample of young men from the NLS, advances more frequently take the form of employer changes as the young workers search for better matches.

\section{Summary and Discussion}

We have attempted a thorough examination of cyclical real wage patterns in the United States since World War II. In Section I, we have considered the prediction of countercyclical real wages that arises from business cycle theories premised on nominal wage stickiness. Like most previous aggregate studies, we find very little evidence of countercyclicality in aggregate industry real wage data. This result becomes more impressive in light of our findings in Section II that the implicit hours-weighting in the aggregate data biases Section I's results in a countercyclical direction.

In Section II, we have considered theories that view cyclical employment fluctuations as the consequence of labor demand shifts (generated by either real or nominal 
disturbances) along a positively sloped short-run labor supply curve. These theories predict procyclical real wages. Our analysis of longitudinal microdata from the Panel Study of Income Dynamics suggests that real wages are indeed quite procyclical. Unlike some recent articles, we conclude that the greater procyclicality in the microdata analysis stems mainly from avoidance of the bias from hours-weighting, not from the choice of sample period. Also, we find that the procyclicality of real wages is about as strong for prime-age male workers that stay with the same employer as for those that change employers. We have proposed an interpretation of these results that involves stickiness in employers' real wage structures, but cyclical variation in their hiring and promotion standards. This interpretation accounts simultaneously for the noncyclicality of real wages in industry average data. the moderate procyclicality in economywide average data, and the strong procyclicality in individual worker data. We believe that further empirical and theoretical research in this area might be especially fruitful.

An important question is whether the evidence that workers' real wages are strongly procyclical should be viewed as corroboration of intertemporal substitution models of the business cycle. We certainly cannot settle the debate over these models, but we can contribute some comments. First, our results on the importance of the hours-weighting bias in aggregate wage measures discredit the use of those measures for testing intertemporal substitution models. Because aggregate real wage measures obscure the true procyclicality of workers' real wages, studies based on such measures inevitably find it difficult to reconcile the small measured cyclical variability in real wages with large cyclical fluctuations in employment. ${ }^{30}$

Second, whether procyclical real wages reflect intertemporal substitution in labor supply depends crucially on whether the workers that receive higher real wages during an expansion are the same ones that work more hours. One interpretation of the recent literature based on longitudinal analysis of earnings and hours microdata is that the two

${ }^{30}$ See, for example, Altonji and Ashenfelter (1980) and Kennan (1988). 
groups of workers do not match up very closely. Abowd and Card (1987, p. 51), ft example, conclude that "a simple interpretation of the data is that earnings and how vary at fixed hourly [real] wage rates. ${ }^{n 1}$

The weak empirical association between real wage changes and hours changes : the individual-worker level may become more understandable if we return to ot distinction between workers that stay with the same employer and those that change. $F_{t}$ stayers, one source of cyclical hours variation is the procyclicality of overtime hours, whic necessarily generates some procyclicality in real wages. Of course, it is possible : interpret the wage premium for overtime as an inducement for intertemporal substitutic in labor supply (see Lucas 1970), but overtime does not appear to be the major source real wage procyclicality for stayers. ${ }^{32}$ The other obvious source of cyclical hou. variation for stayers is cyclicality in temporary layoffs and recalls. We find it implausib that this type of hours variation is a labor supply response to cyclical real wal adjustments. $^{33}$ Our own conjecture, discussed at the end of Section II, is that th procyclicality of stayers' real wages mainly reflects promotions up job ladders, which net not involve any hours changes at all.

Similarly, for employed workers that switch firms, the procyclicality of real wag may reflect cyclicality in opportunities for across-firm career advancement, which aga

${ }^{31}$ See also MaCurdy (1981), Altonji (1986), Ham (1986), and the survey article $\mathrm{t}$ Ashenfelter (1984).

${ }^{32}$ One simple way to see this is to note that the large increase in estimated procyclicali between the first two and the fourth and fifth rows of Table 6 cannot have anything to with overtime because all the wage measures in the table contain overtime. Also, we ha estimated the cyclicality of the overtime hours share in manufacturing, which presumab overstates the economywide cyclicality, and have found that even manufacturing overtime cyclicality can account for at most one-quarter of the procyclicality we ha estimated for real wages.

${ }^{33}$ This observation, however, begs the question of whether such employer-determin hours changes efficiently internalize workers' shadow value of time. Research on th important question has been initiated in several recent studies of employment and wa determination in particular unionized settings. See, for example, Brown and Ashenfelt (1986), MaCurdy and Pencavel (1986), and Card (1988). 
need not involve hours changes. But, for changers shifting between nonemployment and employment, there is a virtually tautological sense in which their hours changes mus reflect intertemporal labor supply behavior. A previously nonemployed individual thui. takes a newly available job during an expansion has revealed a willingness to work at that job's wage and an unwillingness to work at whatever was previously his best availables wage opportunity. Of course, this sort of wage-hours association is not evident in empirical analyses of longitudinal data because the wage opportunities of the nonemployed are not observed. As noted by Lucas (1978), whether one characterizes this aspect of hours and wage cyclicality in the jargon of intertemporal labor supply behavior or in the jargon of involuntary unemployment is not itself of paramount importance. The crucial, and still unresolved, issue is what causes the cyclical variation in employment opportunities. 
Table 1

Results for Average Hourly Earnings Deflated by Implicit GNP Deflator, Major Industries, 1947-48 to 1986-87

\begin{tabular}{|c|c|c|}
\hline & $\hat{\beta}_{3}$ & $\begin{array}{c}\text { Durbin-Watson } \\
\text { statistic }\end{array}$ \\
\hline $\begin{array}{l}\text { Total private } \\
\text { nonagricultural }\end{array}$ & $\begin{array}{r}-.0026 \\
(.0014)\end{array}$ & 1.82 \\
\hline $\begin{array}{l}\text { Manufacturing, } \\
\text { durables }\end{array}$ & $\begin{array}{r}-.0017 \\
(.0013)\end{array}$ & 1.39 \\
\hline $\begin{array}{l}\text { Manufacturing, } \\
\text { nondurables }\end{array}$ & $\begin{array}{l}.0005 \\
(.0012)\end{array}$ & 1.74 \\
\hline Mining & $\begin{array}{c}-.0014 \\
(.0023)\end{array}$ & 1.69 \\
\hline Construction & $\begin{array}{l}.0023 \\
(.0019)\end{array}$ & .96 \\
\hline $\begin{array}{c}\text { Transportation \& } \\
\text { public utilities* }\end{array}$ & $\begin{array}{c}-.0030 \\
(.0030)\end{array}$ & 1.42 \\
\hline Wholesale trade & $\begin{array}{r}-.0005 \\
(.0015)\end{array}$ & 1.78 \\
\hline Retail trade & $\begin{array}{r}-.0012 \\
(.0017)\end{array}$ & 2.08 \\
\hline $\begin{array}{l}\text { Finance, insurance, } \\
\& \text { real estate }\end{array}$ & $\begin{array}{r}-.0005 \\
(.0022)\end{array}$ & 1.11 \\
\hline Services* & $\begin{array}{r}-.0030 \\
(.0024)\end{array}$ & 1.26 \\
\hline
\end{tabular}

Numbers in parentheses are standard error estimates.

*Data available for only 1964-65 to 1986-87. 


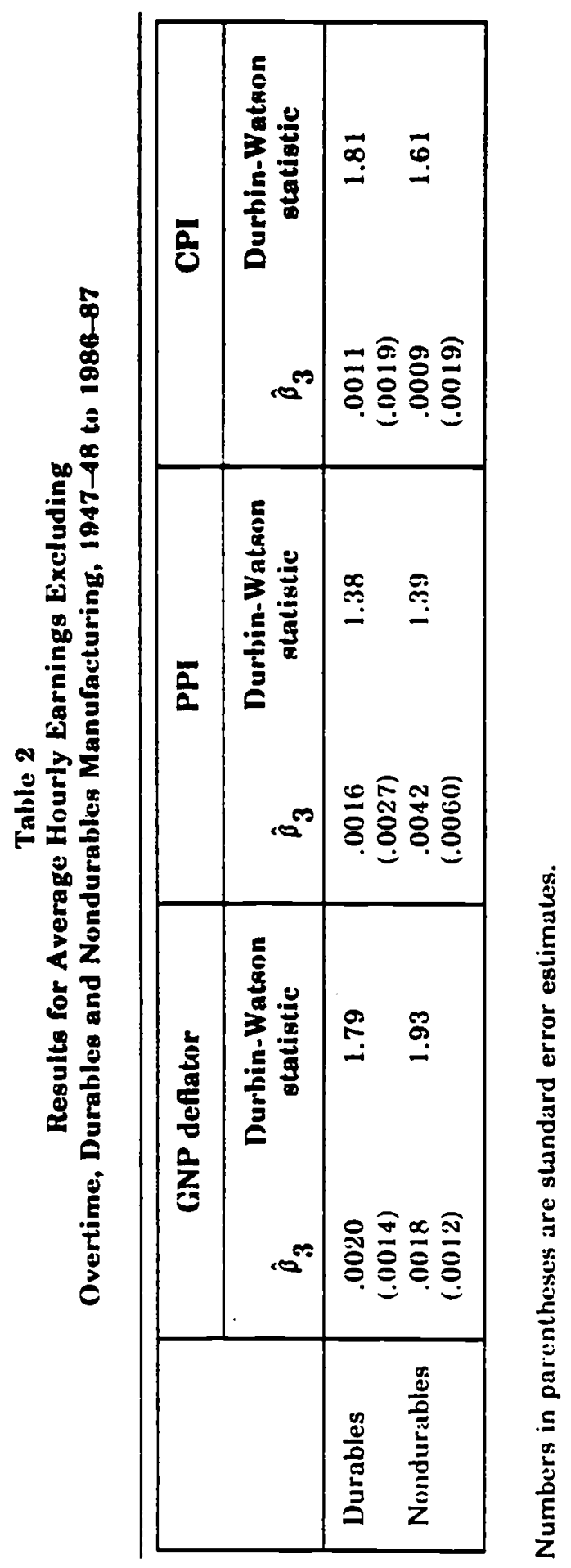




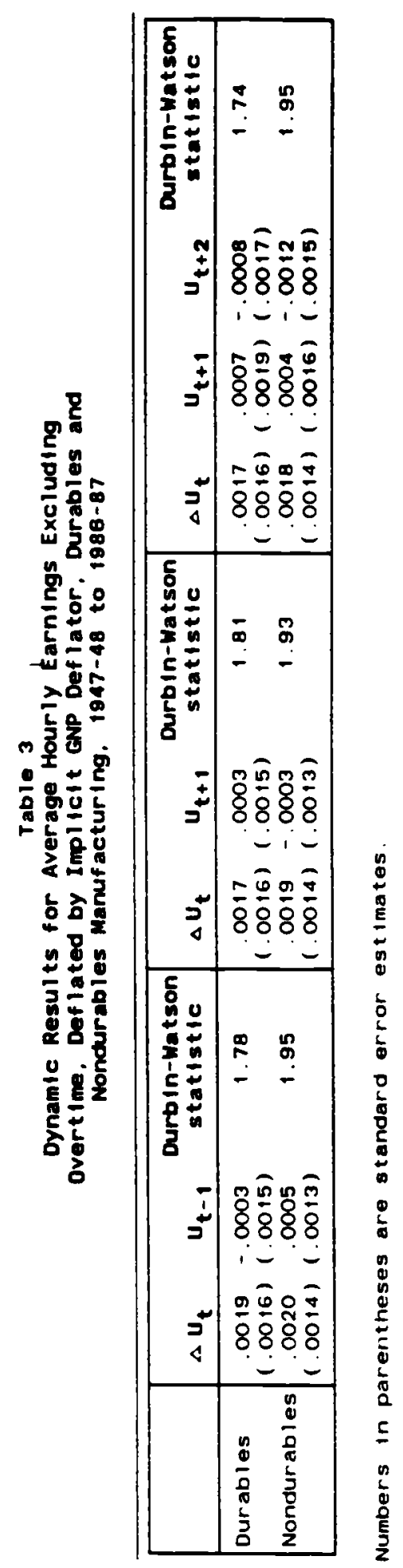


Table 4

Subperiod Results for Average Hourly Earnings

Excluding Overtime, Deflated by Implicit GNP Deflator, Durables and Nondurables Manufacturing

\begin{tabular}{|c|c|c|c|c|}
\hline & \multicolumn{2}{|c|}{$1947-48$ to $1966-67$} & \multicolumn{2}{|c|}{$1967-68$ to $1986-87$} \\
\hline & $\hat{\beta}_{3}$ & $\begin{array}{c}\text { Durbin-Watson } \\
\text { statistic }\end{array}$ & $\hat{\beta}_{3}$ & $\begin{array}{c}\text { Durbin.Watson } \\
\text { statistic }\end{array}$ \\
\hline Durables & .0026 & 2.20 & .0006 & 1.51 \\
\hline Nondurables & $\begin{array}{c}.0037 \\
(.0020)\end{array}$ & 2.00 & $\begin{array}{c}-.0004 \\
(.0014)\end{array}$ & 1.84 \\
\hline
\end{tabular}

Numbers in parentheses are standard error estimates. 


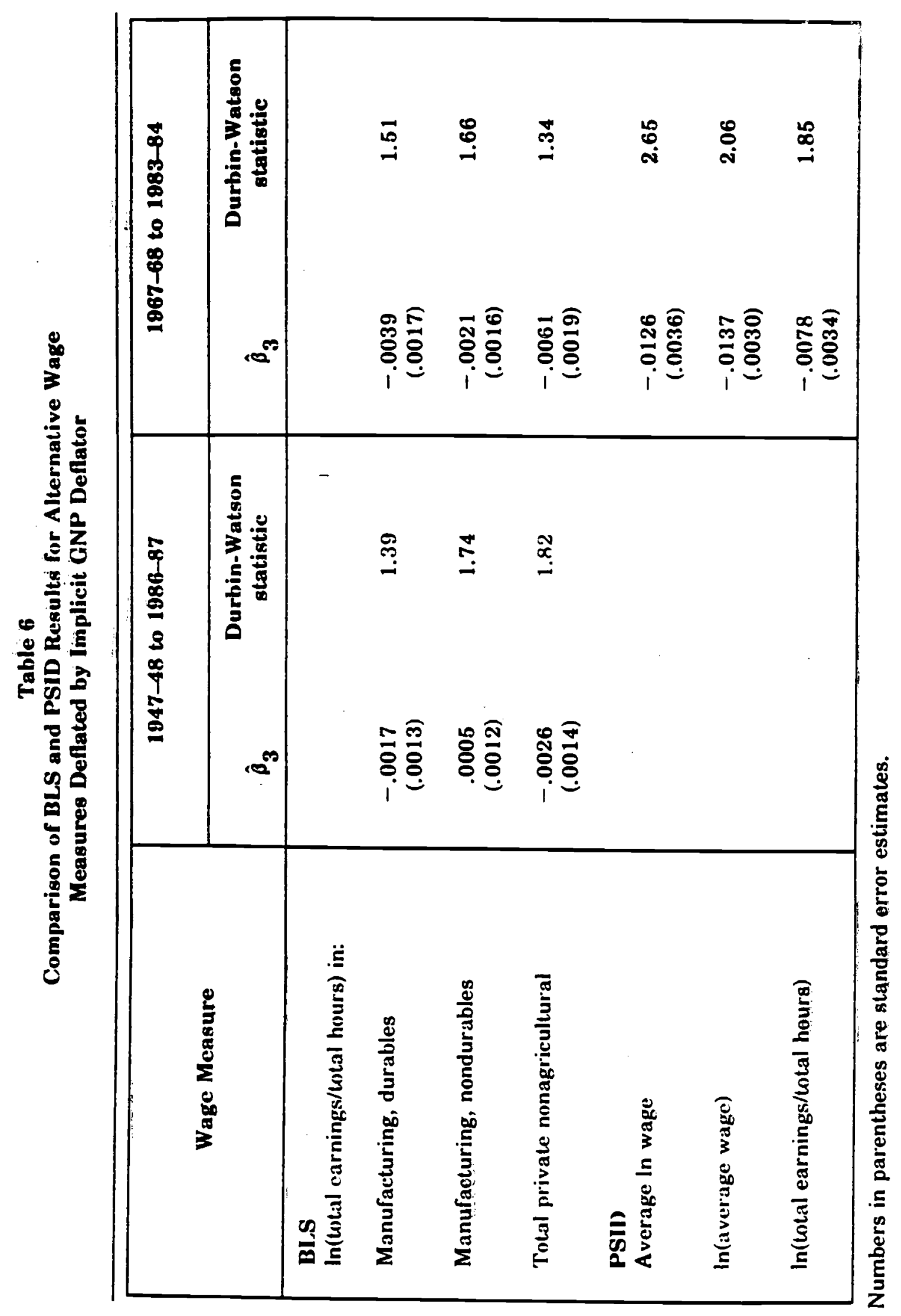




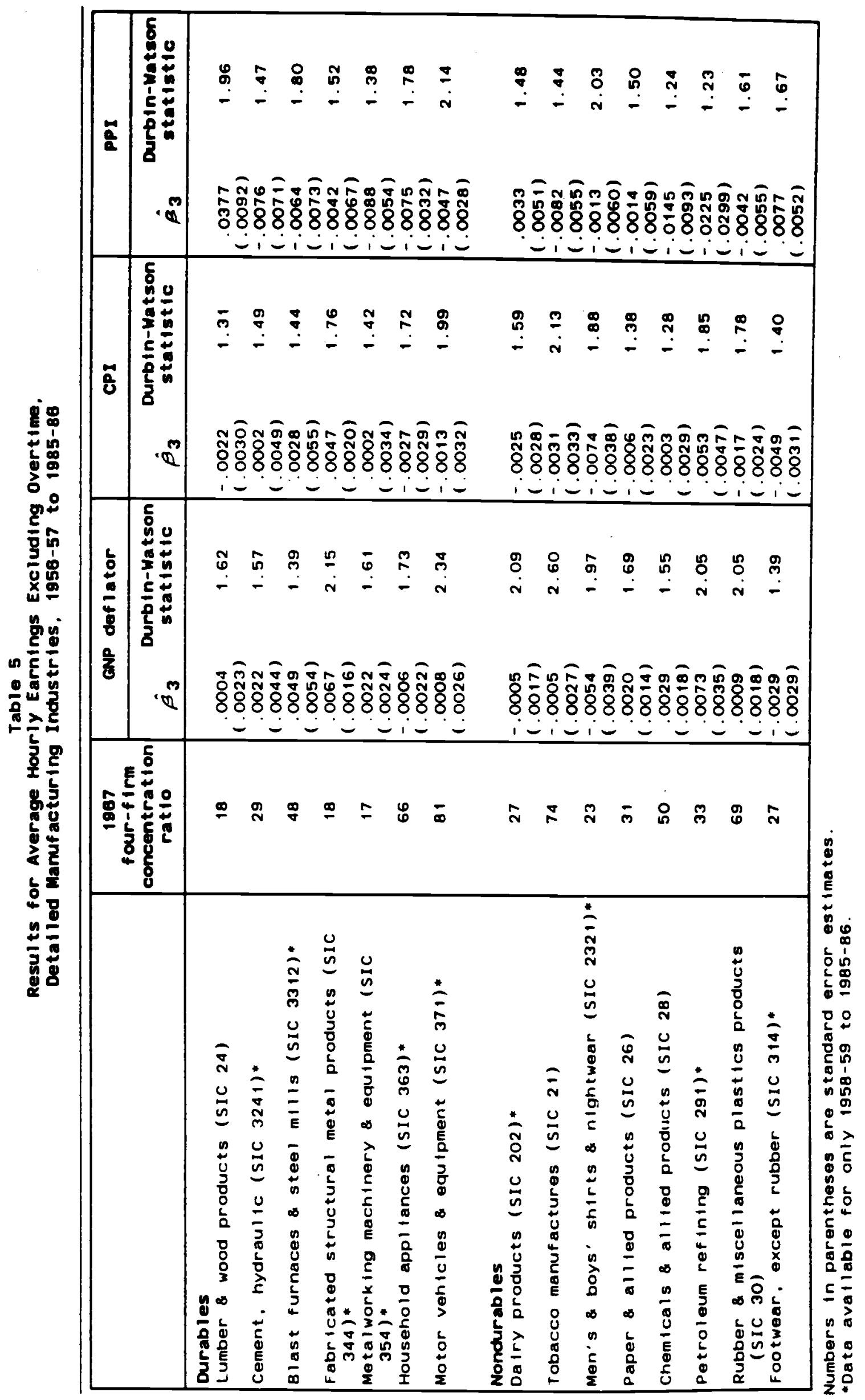


Table 7

PSID Sample's Average Wage Measures, Defiated by Implicit GNP Deflator (1982 Dollars), by Year

\begin{tabular}{|ccc}
\hline Year & Average In wage & In (average wage) \\
\hline 1967 & 2.384 & 2.496 \\
1968 & 2.406 & 2.532 \\
1969 & 2.455 & 2.577 \\
1970 & 2.477 & 2.594 \\
1971 & 2.467 & 2.586 \\
1972 & 2.523 & 2.630 \\
1973 & 2.558 & 2.657 \\
1974 & 2.550 & 2.667 \\
1975 & 2.523 & 2.645 \\
1976 & 2.540 & 2.665 \\
1977 & 2.574 & 2.696 \\
1978 & 2.560 & 2.725 \\
1979 & 2.574 & 2.718 \\
1980 & 2.578 & 2.698 \\
1981 & 2.573 & 2.722 \\
1982 & 2.544 & 2.710 \\
1983 & 2.556 & 2.744 \\
1984 & 2.573 & 2.778 \\
\hline
\end{tabular}


Table 8

Coefficient Estimates from PSID Wage Data Deflated by Implicit GNP Deflator, 1967-68 to 1983-84*

\begin{tabular}{|c|c|c|c|c|}
\hline$\Delta U_{t}$ & $\begin{array}{r}-.0126 \\
(.0031)\end{array}$ & $\begin{array}{r}-.0114 \\
(.0037)\end{array}$ & $\begin{array}{r}-.0148 \\
(.0104)\end{array}$ & $\begin{array}{r}-.0126 \\
(.0037)\end{array}$ \\
\hline$\Delta\left(U_{t} \times\right.$ union dummy $)$ & & $\begin{array}{r}-.0052 \\
(.0067)\end{array}$ & & \\
\hline$\Delta U_{t} \times($ dummy for age $\geq 35)$ & & & $\begin{array}{l}.0025 \\
(.0108)\end{array}$ & \\
\hline $\begin{array}{l}\Delta U_{t} \times \text { (dummy for changing } \\
\text { employers) }\end{array}$ & & & & $\begin{array}{r}-.0019 \\
(.0071)\end{array}$ \\
\hline
\end{tabular}

See text for discussion of downward bias in standard error estimates. which appear in parentheses.

*The results in the second and fourth columns are for 1968-69 to 1983-84 because of the unavailability of union status and job tenure measures for 1967 . The coefficient estimate in the first column changes to -.0130 if $1967-68$ is excluded. 


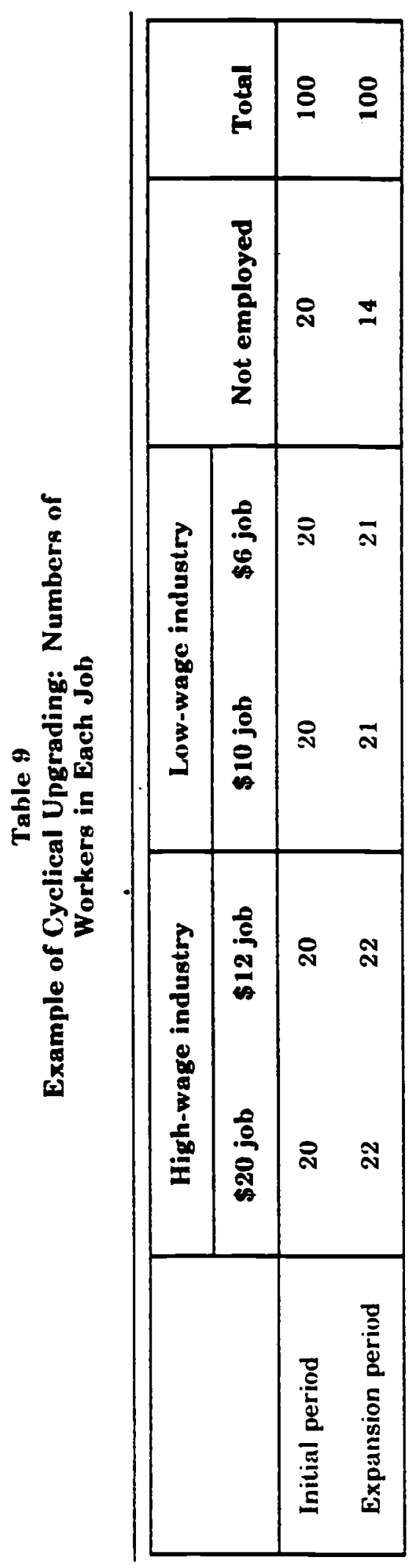




\section{APPENDIX: DATA SOURCES}

\section{Aggregate Data}

Civilian unemployment rate and employment/population ratio: Economic Report of the President, 1988, Table B.32.

Real GNP: Economic Report of the President, 1988, Table B-2.

Implicit GNP deflator: Economic Report of the President, 1988, Table B-3.

Consumer price index: Economic Report of the President, 1988, Table B-58.

Producer price indexes: The PPIs for durable goods and nondurable goods manufacturing come from Handbook of Labor Statistics, 1975, Table 133, for 1947-59; Handbook of Labor Statistics, 1985, Table 113, for 1960-83; Supplements to Producer Price Indexes, 1984-85, Table 2, for 1984-85; and Monthly Labor Revieu, February 1988, Table 34, for 1986-87. The PPIs for the detailed industries other than men's and boys' shirts and nightwear, cement-hydraulic, and blast furnaces and steel mills come from Handbook of Labor Statistics, 1975, Table 132, for 1956-59; Handbook of Labor Statistics, 1985, Table 112, for 1960-83; and Supplements to Producer Price Indexes, 1984-86, Table 4, for 1984-86. The PPIs for men's and boys' shirts and nightwear, cement-hydraulic, and blast furnaces and steel mills come from Handbook of Labor Statistics, 1975, Table 135, for 1957-58; Handbook of Labor Statistics, 1985, Table 114, for 1959-82; and Supplements to Producer Price Indexes, 1983-86, Table 3, for 1983-86. Because these three industries' published PPIs for $1983-86$ are relative to a different base year than are their published PPIs for earlier years, it is necessary to splice the series. The required information comes from Supplement to Producer Price Indexes, 1982, Table 3, and Producer Price Indexes, June 1983, Table 9.

Average hourly earnings: Average hourly earnings of production or nonsupervisory workers in total private nonagricultural employment and by major industry come from Handbook of Labor Statistics, 1975, Table 98, for 1947-63 and Employment and Earnings, April 1988, Table C-1, for 1964-87. Average hourly earnings 
excluding overtime in durables and nondurables manufacturing and in two-digit industries come from Handbook of Labor Statistics, 1975, Table 101, for 1947-59 and Handbook of Labor Statistics, 1985, Table 77, for 1960-83, For 1984-87 (1984-86 for two-digit industries), average hourly earnings excluding overtime are imputed from the formula $W /\left[1+\frac{1}{2}(O / H)\right]$ where $W$ is average hourly earnings (including overtime), $H$ is average weekly hours, and $O$ is average weekly overtime hours. This is the same formula used by the Bureau of Labor Statistics to construct its published series on average hourly earnings excluding overtime. The data on $\mathrm{W}, \mathrm{H}$, and $\mathrm{O}$ for durables and nondurables manufacturing come from Employment and Earnings, January 1988, Table 65, and the data for two-digit industries come from Supplement to Employment and Earnings, July 1987. Average hourly earnings excluding overtime in three-and four-digit industries are imputed in the same manner from data in Employment and Earnings, United States, 190978 for 1956-76; Supplement to Employment and Earnings, July 1984, for 1977-82; and Supplement to Employment and Earnings, July 1987, for 1983-86.

1967 four-firm concentration ratios: The ratios for two-digit industries are drawr from Rotemberg and Saloner (1986, Table 2). The ratios for four-digit industries come from Concentration Ratios in Manufacturing, 1977 Census of Manufactures, Table 7. The ratios for three-digit industries are constructed from the same source by the same averaging procedure described in Rotemberg and Saloner.

\section{Panel Study of Income Dynamics}

Our data are drawn from the 1985 cross-year family-individual response file which is documented in A Panel Study of Income Dynamics: Procedures and Tape Codes 1985 Interviewing Year - Wave XVIII, A Supplement. Institute for Social Research University of Michigan, 1988. The data were collected in annual interviews from $1968 \mathrm{th}$ 1985. The responses concerning annual labor income and hours of work pertain to thi preceding calendar years 1967-84, while the responses concerning union status and jol tenure pertain to current employment as of the interview date. Individuals with "majo 
assignments" imputed for labor income or work hours in any year are excluded from our sample. Details on variable construction are given below.

Hourly wage rate: Ratio of annual labor income to annual hours of work.

Years of work experience: Calendar year minus birth year minus years of education minus 6. The education variable (taken from the value recorded in the 1984 interview) is highest grade completed with the category 17 or more assigned a value of 18 .

Union status: For 1968-72 and 1974-81, we classify a worker as a union member if he responded affirmatively to the question "Do you belong to a labor union?" For 1982-84, we classify him as a union member if he responded affirmatively to both "Is your current job covered by a union contract?" and "Do you belong to that labor union?" To assure that the resulting variable is sufficiently consistent over time, we have examined the years 1976-81, when both question sequences were asked, and found that the outcomes of our two classification procedures match up quite closely. In the 1973 survey, union status was not elicited. We classify a worker as a union member in 1973 if (1) he had been in his current job for at least a year and was a union member in 1972 or (2) he had been in his current job for less than a year, indicated in 1974 that he had been in his 1974 job for at least a year, and ras a union member in 1974. Our construction of the union variable takes account of the fact that it pertains to current status as of the interview date, unlike the income and work hours questions. which refer to the preceding calendar year. For example, our 1984 wage variable is based on the 1985 interview responses about labor income and work hours, while the 1984 union status variable is based on the 1984 interview.

Tenure with employer: See Altonji and Shakotko (1985, Appendix 2). Our use of this variable to identify "stayers" is described in the text. 


\section{References}

Abowd, John M., and Card, David, "Intertemporal Labor Supply and Long-Terr Employment Contracts," American Economic Review, March 1987, 77, 50-68.

Altonji, Joseph G., "Intertemporal Substitution in Labor Supply: Evidence from Micr Data," Journal of Political Economy, June 1986, 94, S176-215.

and Ashenfelter, Orley, "Wage Movements and the Labour Market Equilibriur Hypothesis," Economica, August 1980, 47, 217-45.

and Shakotko, Robert, "Do Wages Rise with Job Seniority?" Working Pape No. 1616, National Bureau of Economic Research, May 1985.

Ashenfelter, Orley, "Macroeconomic Analyses and Microeconomic Analyses of Labo Supply," Carnegie-Rochester Conference Series on Public Policy, Autumn 1984, 21 $117-55$

Barro, Robert J., and King, Robert G., "Time-Separable Preferences and Intertempora Substitution Models of Business Cycles," Quarterly Journal of Economics, Novembe $1984,99,817-39$.

Barsky, Robert B., and Miron, Jeffrey A., "The Seasonal Cycle and the Business Cycle, Journal of Political Economy, forthcoming.

Bils, Mark J., "Real Wages over the Business Cycle," Journal of Political Economy, Augus $1985,93,666-89$.

Bodkin, Ronald G., "Real Wages and Cyclical Variations in Employment," Canadia Journal of Economics, August 1969, 2, 353-74.

Brown, James N., and Ashenfelter, Orley, "Testing the Efficiency of Employmer Contracts," Journal of Political Economy, June 1986, 94, S40-87.

Card, David, "Unexpected Inflation, Real Wages, and Employment Determination in Unio Contracts," unpublished, May 1988.

Carr, Darrell E., "Overtime Work: An Expanded View," Monthly Labor Review, Novembe 1986, 109, 36-39.

Chirinko, Robert S., "The Real Wage Rate over the Business Cycle," Review of Ecanomic and Statistics, August 1980, 62, 459-61.

Clark, Kim B., and Summers, Lawrence H., "Demographic Differences in Cyclic Employment Variation," Journal of Human Resources, Winter 1981, 16, 61-79.

Coleman, Thomas S., "Essays in Aggregate Labor Market Business Cycle Fluctuations unpublished dissertation, University of Chicago, December 1984.

, "A Note on the Measurement of Aggregate Effects in Panel Data unpublished. November 1986.

Doeringer, Peter B., and Piore, Michael J., Internal Labor Markets and Manpower Analysi Lexington: D. C. Heath, 1971. 
Domowitz, Ian, Hubbard, R. Glenn, and Petersen, Bruce C., "Market Structure and Cyclical Fluctuations in U.S. Manufacturing," Review of Economics and Statistics, February 1988, 70, 55-56.

Freeman, Richard B., and Medoff, James L., "New Estimates of Private Sector Unionism in the United States," Industrial and Labor Relations Review, January 1979, 32, 143-74.

Friedman, Milton, "The Role of Monetary Policy," American Economic Review, March $1968,58,1-17$.

Geary, Patrick T., and Kennan, John, "The Employment-Real Wage Relationship: An International Study," Journal of Political Economy, April 1982, 90, 854-71.

Hall, Robert E., "The Process of Inflation in the Labor Market," Brookings Papers on Economic Activity, 1974:2, 343-93.

, "The Rigidity of Wages and the Persistence of Unemployment," Brookings Papers on Economic Activity, 1975:2, 301-35.

, "The Importance of Lifetime Jobs in the U.S. Economy," American Economic Review, September 1982, 72, 716-24.

, "Examining Alternative Macroeconomic Theories: Comment," Brookings Papers on Economic Activity, 1988:1, 261-64.

and Taylor, John B., Macroeconomics: Theory, Performance, and Policy, New York: W. W. Norton, 1986.

Ham, John C., "Testing Whether Unemployment Represents Intertemporal Labour Supply Behaviour," Review of Economic Studies, August 1986, 53, 559-78.

Hart, Oliver D., "Optimal Labour Contracts under Asymmetric Information," Review of Economic Studies, January 1983, 50, 3-35.

Hildebrand, George H., "External Influence and the Determination of the Internal Wage Structure," in L. J. Meij, ed., Internal Wage Structure, Amsterdam: North.Holland, 1963.

Huizinga, John P., "Real Wages, Employment and Expectations," unpublished dissertation, MIT, June 1980.

Keane, Michael, Moffitt, Robert, and Runkle, David, "Real Wages over the Business Cycle: Estimating the Impact of Heterogeneity with Micro Data," Journal of Political Economy, December 1988, 96, 1232-66.

Kennan, John, "An Econometric Analysis of Fluctuations in Aggregate Labor Supply and Demand," Econometrica, March 1988, 56, 317-33.

Keynes, John Maynard, The General Theory of Employment, Interest, and Money, London: Macmillan, 1936. 
Kniesner, Thomas J., and Goldsmith, Arthur H., "A Survey of Alternative Models of the Aggregate U.S. Labor Market," Journal of Economic Literature, September 1987, $25,1241-80$.

Kydland, Finn E., "Labor-Force Heterogeneity and the Business Cycle," CamegieRochester Conference Series on Public Policy, Autumn 1984, 21, 173-208.

Leamer, Edward E., "Is It a Demand Curve, or Is It a Supply Curve? Partial Identification through Inequality Constraints," Review of Economics and Statistics, August 1981, 63, 319-27.

Lilien, David M., and Hall, Robert E., "Cyclical Fluctuations in the Labor Market," in Orley Ashenfelter and Richard Layard, eds., Handbook of Labor Economics, Amsterdam: North.Holland, 1986, 1001-35.

Lucas, Robert E., Jr., "Capacity, Overtime, and Empirical Production Functions," American Economic Review, May 1970, 60, 23-27.

, "Understanding Business Cycles." Carnegie-Rochester Conference Series on Public Policy, 1977, 5, 7-29.

, "Unemployment Policy," American Economic Review, May 1978, 68, 353-57.

and Rapping, Leonard A.. "Real Wages, Employment, and Inflation," Journal of Political Economy, September-October 1969, 77, 721-54.

MaCurdy, Thomas E., "An Empirical Model of Labor Supply in a Life-Cycle Setting," Journal of Political Economy, December 1981, 89, 1059-85.

"The Use of Time Series Processes to Model the Error Structure of Earnings in a Longitudinal Data Analysis," Journal of Econometrics, January 1982, 18, 83-114.

and Pencavel, John H., "Testing between Competing Models of Wage and Employment Determination in Unionized Markets," Journal of Political Economy, June 1986, 94, S3-39.

Mather, Jane E., "In Search of Cyclical Wage Differentials," unpublished, March 1987.

Mincer, Jacob, Schooling, Experience, and Earnings, New York: National Bureau of Economic Research, 1974.

Mitchell, Mark L., Wallace, Myles S., and Warner, John T., "Real Wages over the Business Cycle: Some Further Evidence," Southern Economic Journal, April 1985, 51, 1162-73.

Neftci, Salih N., "A Time-Series Analysis of the Real Wages-Employment Relationship," Journal of Political Economy, April 1978, 86, 281-91.

Okun, Arthur M., "Upward Mobility in a High-Pressure Economy," Brookings Papers on Economic Activity, 1973:1, 207-52.

, Prices and Quantities: A Macroeconomic Analysis, Washington: Brookings Institution, 1981. 
Pencavel, John, and Hartsog, Catherine E., "A Reconsideration of the Effects of Unionism on Relative Wages and Employment in the United States, 1920-1980," Joumal of Labor Economics, April 1984, 2, 193-232.

Phelps, Edmund S., "Introduction: The New Microeconomics in Employment and Inflation Theory," in Edmund S. Phelps, ed., Microeconomic Foundations of Employment and Inflation Theory, New York: W. W. Norton, 1970, 1-23.

Prescott, Edward C., "Response to a Skeptic," Federal Reserve Bank of Minneapolis Quarterly Review, Fall 1986, 10, 28-33.

Raisian, John, "Cyclic Patterns in Weeks and Wages," Economic Inquiry, October 1979, 17, 475-95.

Reder, Melvin W., "The Theory of Occupational Wage Differentials," American Economic Revieu, December 1955, 45, 833-52.

Rotemberg, Julio J., and Saloner, Garth, "A Supergame-Theoretic Model of Price Wars during Booms," American Economic Review, June 1986, 76, 390-407.

Sargent, Thomas J., "Estimation of Dynamic Labor Demand Schedules under Rational Expectations," Journal of Political Economy, December 1978, 86, 1009-44.

Stockman, Alan C., "Aggregation Bias and the Cyclical Behavior of Real Wages," unpublished, July 1983.

Topel, Robert, "Wages Rise with Job Seniority," unpublished, November 1987. 